\title{
A Depolarizing Chloride Current Contributes to Chemoelectrical Transduction in Olfactory Sensory Neurons In Situ
}

\author{
Dirk Reuter, ${ }^{1}$ Karl Zierold, ${ }^{2}$ Walter H. Schröder, ${ }^{1}$ and Stephan Frings ${ }^{1}$ \\ 1/nstitut für Biologische Informationsverarbeitung, Forschungszentrum Jülich, 52425 Jülich, Germany, and 2Max-Planck- \\ Institut für Molekulare Physiologie, Rheinlanddamm 201, 44139 Dortmund, Germany
}

\begin{abstract}
Recent biophysical investigations of vertebrate olfactory signal transduction have revealed that $\mathrm{Ca}^{2+}$-gated $\mathrm{Cl}^{-}$channels are activated during odorant detection in the chemosensory membrane of olfactory sensory neurons (OSNs). To understand the role of these channels in chemoelectrical signal transduction, it is necessary to know the $\mathrm{Cl}^{-}$-equilibrium potential that determines direction and size of $\mathrm{Cl}^{-}$fluxes across the chemosensory membrane. We have measured $\mathrm{Cl}^{-}, \mathrm{Na}^{+}$, and $\mathrm{K}^{+}$concentrations in ultrathin cryosections of rat olfactory epithelium, as well as relative element contents in isolated microsamples of olfactory mucus, using energy-dispersive $\mathrm{x}$-ray microanalysis. Determination of the $\mathrm{Cl}^{-}$concentrations in dendritic knobs and olfactory mucus yielded an estimate of the $\mathrm{Cl}^{-}$-equilibrium potential $E_{\mathrm{Cl}}$ in situ. With $\mathrm{Cl}^{-}$concentrations of $69 \mathrm{~mm}$ in
\end{abstract}

Detection of odorants in vertebrates is mediated by olfactory sensory neurons (OSNs) within the olfactory neuroepithelium (Fig. 1A). Each OSN projects a single dendrite to the epithelial surface where 10-20 cilia emanate from the dendritic knob, the apical ending of the dendrite (Fig. $1 B$ ). Olfactory cilia are embedded in a mucus layer that forms a distinct epithelial fluid compartment (Getchell et al., 1988; Menco, 1995), separated from interstitial fluid by tight junctions (Kerjaschki and Hörandner, 1976). Several steps of the chemoelectrical transduction sequence have been established (Fig. 2). Odorants dissolve in the mucus and bind to odorant-receptor proteins in the ciliary membrane (Breer et al., 1996; Buck, 1996). Receptor proteins for most odorants induce synthesis of the second messenger cAMP through activation of adenylyl cyclase (Lowe et al., 1989; Bakalyar and Reed, 1990; Boekhoff et al., 1990). Cyclic nucleotidegated $(\mathrm{CNG})$ channels, expressed at high density in the ciliary membrane, are activated on binding of cAMP (Nakamura and Gold, 1987; Zufall et al., 1994) and conduct influx of monovalent cations and $\mathrm{Ca}^{2+}$ from the mucus into the ciliary lumen (Firestein and Werblin, 1987; Frings et al., 1995), causing depolarization of membrane voltage as well as an increase of the ciliary $\mathrm{Ca}^{2+}$ concentration (Leinders-Zufall et al., 1997). While depolarization leads to electrical excitation of the neuron, the $\mathrm{Ca}^{2+}$ signal

\footnotetext{
Received March 12, 1998; revised May 27, 1998; accepted June 2, 1998.

This work was supported by the Deutsche Forschungsgemeinschaft, Schwerpunktprogramm "Molekulare Sinnesphysiologie." We gratefully acknowledge the assistance of Sabine Dongard, Ulrich Horsten, Hans-Peter Bochem, Drs. Stephan Marienfeld and Arnd Kuhn with the preparation of electron micrographs and the EDX measurements. We thank Drs. Gordon L. Fain, U. Benjamin Kaupp, and Frank Müller for reading this manuscript, and Dieter Grammig for the art work.

Correspondence should be addressed to Dr. Stephan Frings, Institut für Biologische Informationsverarbeitung, Forschungszentrum Jülich, 52425 Jülich, Germany. Copyright (C) 1998 Society for Neuroscience $\quad 0270-6474 / 98 / 186623-08 \$ 05.00 / 0$
}

dendritic knobs and $55 \mathrm{~mm}$ in olfactory mucus, we obtained an $E_{\mathrm{Cl}}$ value of $+6 \pm 12 \mathrm{mV}$. This indicates that $\mathrm{Ca}^{2+}$-gated $\mathrm{Cl}^{-}$ channels in olfactory cilia conduct inward currents in vivo carried by $\mathrm{Cl}^{-}$efflux into the mucus. Our results show that rat OSNs are among the few known types of neurons that maintain an elevated level of cytosolic $\mathrm{Cl}^{-}$. In these cells, activation of $\mathrm{Cl}^{-}$channels leads to depolarization of the membrane voltage and can induce electrical excitation. The depolarizing $\mathrm{Cl}^{-}$current in mammalian OSNs appears to contribute a major fraction to the receptor current and may sustain olfactory function in sweet-water animals.

Key words: olfaction; olfactory sensory neurons; mucus; chloride channels; chloride concentration; receptor current; sensory transduction; EDX microanalysis terminates the sensory response through activation of phosphodiesterase (Borisy et al., 1992) and through a calmodulinmediated negative feedback regulation of CNG channel activity (Chen and Yau, 1994; Kurahashi and Menini, 1997).

An important addition to this transduction scheme is the recent discovery of $\mathrm{Ca}^{2+}$-gated $\mathrm{Cl}^{-}$channels, also expressed in the ciliary membrane and activated when the ciliary $\mathrm{Ca}^{2+}$ concentration rises to micromolar levels (Kleene and Gesteland, 1991; Kleene, 1993, 1997; Hallani et al., 1998). These channels can conduct substantial currents across the ciliary membrane (Kurahashi and Yau, 1993; Lowe and Gold, 1993; Kleene et al., 1994), depending on membrane voltage and the $\mathrm{Cl}^{-}$concentrations in mucus and ciliary lumen. If the $\mathrm{Ca}^{2+}$-induced $\mathrm{Cl}^{-}$flux in situ is outward-directed (from ciliary lumen to mucus), the combined activation of $\mathrm{CNG}$ channels and $\mathrm{Cl}^{-}$channels results in a pronounced nonlinear amplification of the receptor current (Lowe and Gold, 1993). Furthermore, the relatively low $\mathrm{Ca}^{2+}$ sensitivity of the $\mathrm{Cl}^{-}$channels $\left(K_{1 / 2}=5 \mu \mathrm{M}\right)$ (Kleene and Gesteland, 1991) may introduce an excitation threshold and thereby improve noise suppression in OSNs.

These concepts represent important novel aspects of olfactory signal transduction, but they cannot be validated unless the ion concentrations that determine currents across the ciliary membrane in vivo are known. In particular, the $\mathrm{Cl}^{-}$concentrations in olfactory mucus and ciliary lumen have to be established to assess direction and size of the $\mathrm{Ca}^{2+}$-activated $\mathrm{Cl}^{-}$flux. We have used energy-dispersive $\mathrm{x}$-ray (EDX) microanalysis to measure $\mathrm{Cl}^{-}$ concentrations in dendritic knobs and olfactory mucus. We obtained an estimate for the $\mathrm{Cl}^{-}$equilibrium potential in situ, and our results support the proposed role of $\mathrm{Ca}^{2+}$-gated $\mathrm{Cl}^{-}$channels in the generation of the receptor current in OSNs. 

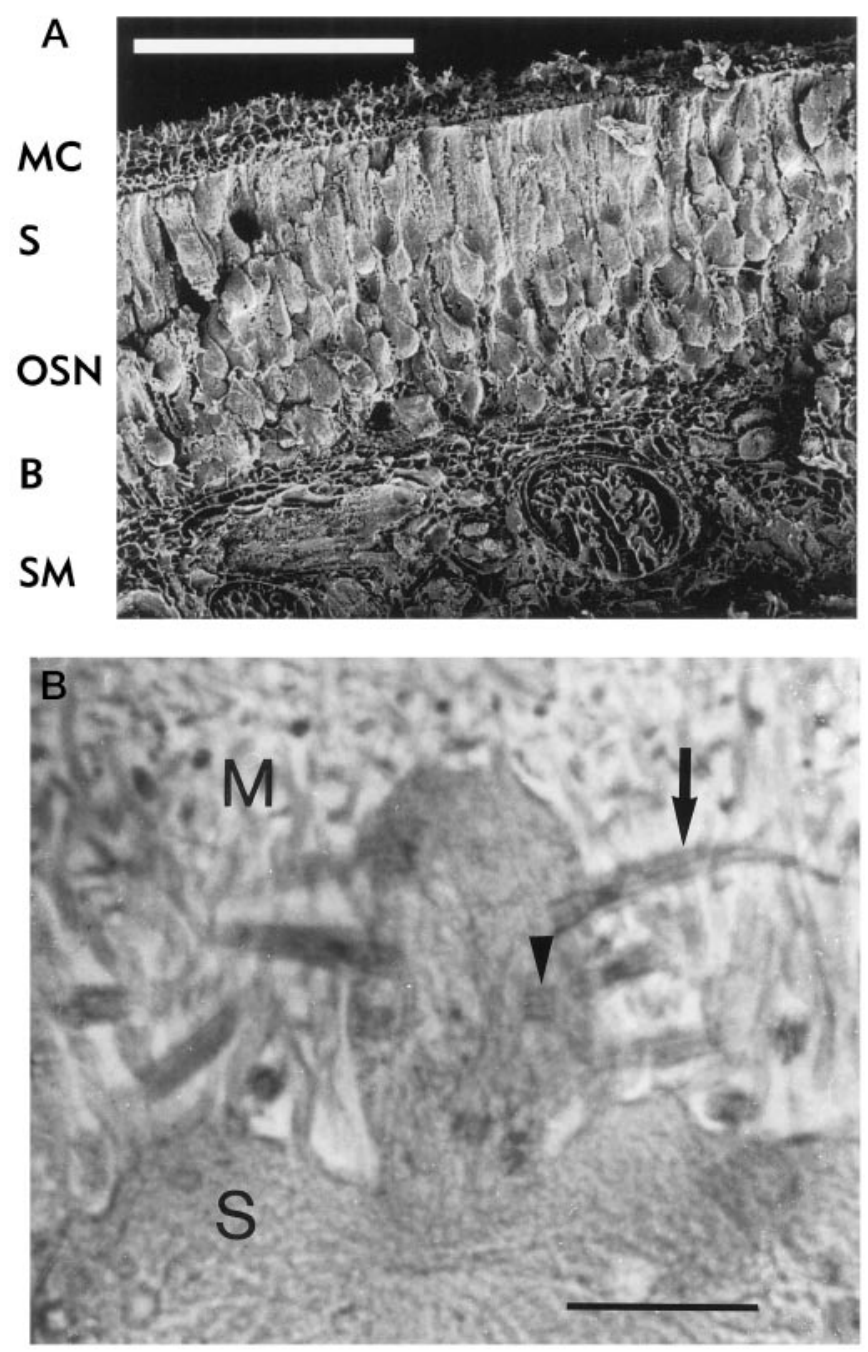

Figure 1. Morphology of rat olfactory epithelium. A, Scanning electron micrograph of a freeze-dried preparation of rat olfactory epithelium showing mucociliary complex $(M C)$, a single layer of epithelial supporting cells $(S)$, the somata of olfactory sensory neurons $(O S N)$, basal cells that form a reservoir of undifferentiated neurons $(B)$, and submucosal tissue $(S M)$ with connective tissue, blood vessels, and nerve bundles. Dendritic knobs cannot be seen at this magnification. Scale bar, $100 \mu \mathrm{m}$. B, Transmission electron micrograph of the mucociliary complex showing the boundary between supporting cells $(S)$ and olfactory mucus $(M)$. A dendritic knob can be seen with longitudinal (arrow) and transversal (arrowhead) sections of sensory cilia. Scale bar, $1 \mu \mathrm{m}$.

\section{MATERIALS AND METHODS}

Animals. Sprague Dawley rats (3-6 weeks old) were killed by cervical dislocation. The nasal cavity was opened by a sagittal incision along either side of the septum that exposed the olfactory turbinates (conchae) lined with olfactory epithelium. All experiments were performed with tissue that showed no sign of mechanical damage and was not contaminated with blood.

Preparation of olfactory epithelium for EDX microanalysis. Shortly after the animal was killed, whole conchae were dissected from the olfactory turbinates and plunged into liquid propane $\left(-150\right.$ to $\left.-190^{\circ} \mathrm{C}\right)$ for cryofixation. This method ensures rapid freezing of the tissue and preserves both tissue structure and spatial distribution of elements close to the native state (Zierold, 1992; Zierold et al., 1994). After cryofixation, tissue samples were stored in liquid nitrogen.

To prepare cryosections for EDX microanalysis in the scanning transmission electron microscope (STEM), cryofixed conchae were glued to cryoultramicrotome holders with liquid heptane and cut dry at $-125^{\circ} \mathrm{C}$ (Ultracut with FC4 cryokit, Reichert-Jung) (Seveus, 1980; Zierold,

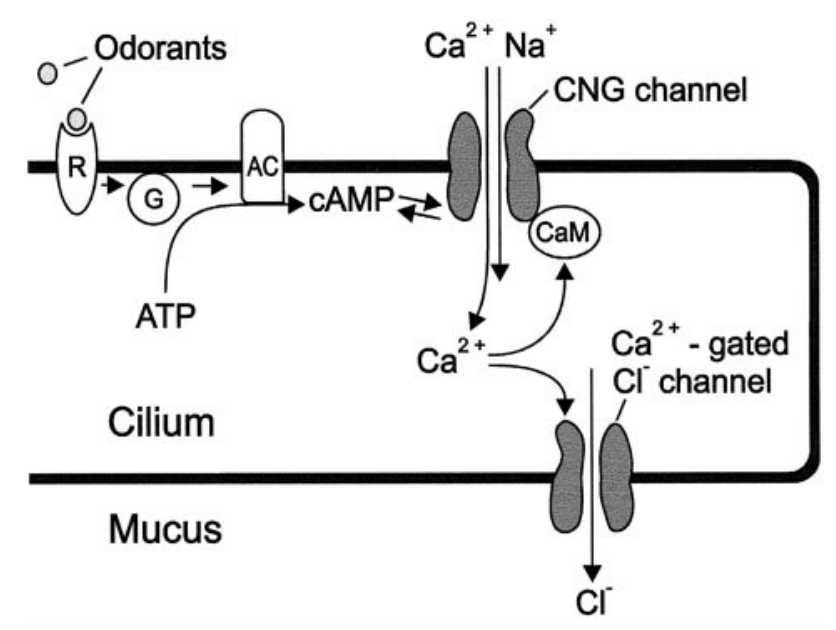

Figure 2. Schematic representation of a sensory cilium with the main components of cAMP-mediated olfactory signal transduction. $R$, Odorant receptor; $G$, GTP-binding protein; $A C$, adenylyl cyclase; $C a M$, calmodulin.

1982). Cryosections (100 nm thick) were freeze-dried in the cryotransfer chamber at -90 to $-80^{\circ} \mathrm{C}$ for $10-15$ min and subsequently transferred into a STEM (Siemens Elmiskop ST 100F, equipped with a cold stage), where they were analyzed at $-135^{\circ} \mathrm{C}$. EDX spectra were recorded using a SiLi-detector (Nuclear Semiconductor) and analyzed with a Link Multichannel Analyzer (Zierold, 1988).

Quantitative evaluation of the measured x-ray spectra was performed as described previously (Zierold, 1988). By comparison with measurements of cryosections of known thickness obtained from reference material (dextran mixed with electrolyte solution of known element content), quantitative element contents, $c_{\mathrm{d}}$, in terms of millimole/kilogram dry mass, were obtained according to the peak-to-background method. The local dry mass content $(d)$ and the corresponding water content $(1-$ $d$ ) were determined by measuring the dark-field intensity in STEM obtained from the cryosections and the support film, as described elsewhere (Zierold, 1986). Then, the element concentration, $c_{\mathrm{w}}$, in terms of millimole/kilogram water, was calculated according to the formula $c_{\mathrm{w}}=$ $c_{\mathrm{d}} \times d(1-d)$.

Determination of $\mathrm{Cl} / \mathrm{K}$ ratios in isolated microsamples of olfactory mucus. To remove small samples of olfactory mucus, carbon-coated nylon grids (diameter $3 \mathrm{~mm}, 200 \mathrm{mesh}$; Plano) were brought into contact with the epithelial surface of conchae in situ using microforceps. The samples were air-dried in a dust-proof container and transferred into a transmission electron microscope (Philips EM $400 \mathrm{~T}$ ). Energy dispersive x-ray spectra were recorded with an electron beam of $100 \mathrm{kV}$ acceleration voltage using a BeGe-detector (Noran, Middleton, WI). EDX spectra were evaluated using the program DTSA (Desk Top Spectrum Analyzer) by the National Institute of Standards (USA). The background continuum spectrum and the characteristic element spectra were determined using a polynomial fit, and peak-to-background ratios were calculated for $\mathrm{Cl}$ and $\mathrm{K}$ (Barbi, 1979). To minimize variations between samples, measurements were taken from samples of similar area $\left(10-50 \mu \mathrm{m}^{2}\right)$ and similar thickness (estimated from the intensity of electron transmission).

Preparation of olfactory epithelium for scanning electron microscopy. For EDX microanalysis in the scanning electron microscope (SEM), the tissue was first freeze-dried at $-80^{\circ} \mathrm{C}, 0.04 \mathrm{hPa}$ for $80-100 \mathrm{hr}$ (Secfroid, Morand, France). The freeze-dried conchae were then fractured with a scalpel, carbon-coated, and transferred into an SEM (Cambridge Instruments) equipped with a SiLi-detector for EDX microanalysis (Tracor, Bruchsal, Germany). To better visualize the structure of freeze-dried olfactory cilia after EDX microanalysis, the specimens were coated with a gold layer and photographed in an SEM (Jeol JSM 6300f) equipped with a cold field-emission gun.

Preparation of olfactory epithelium for transmission electron microscopy. After cryofixation, olfactory conchae were subjected to cryosubstitution (Schröder and Fain, 1984). The samples were incubated for $90 \mathrm{hr}$ at $-80^{\circ} \mathrm{C}$ in acetone containing $2 \% \mathrm{OsO}_{4}$, followed by $24 \mathrm{hr}$ in acetone without $\mathrm{OsO}_{4}$. After three $24 \mathrm{hr}$ periods in acetone at $-20^{\circ} \mathrm{C}$, samples were embedded in epoxy resin at room temperature (Spurr, 1969) and 

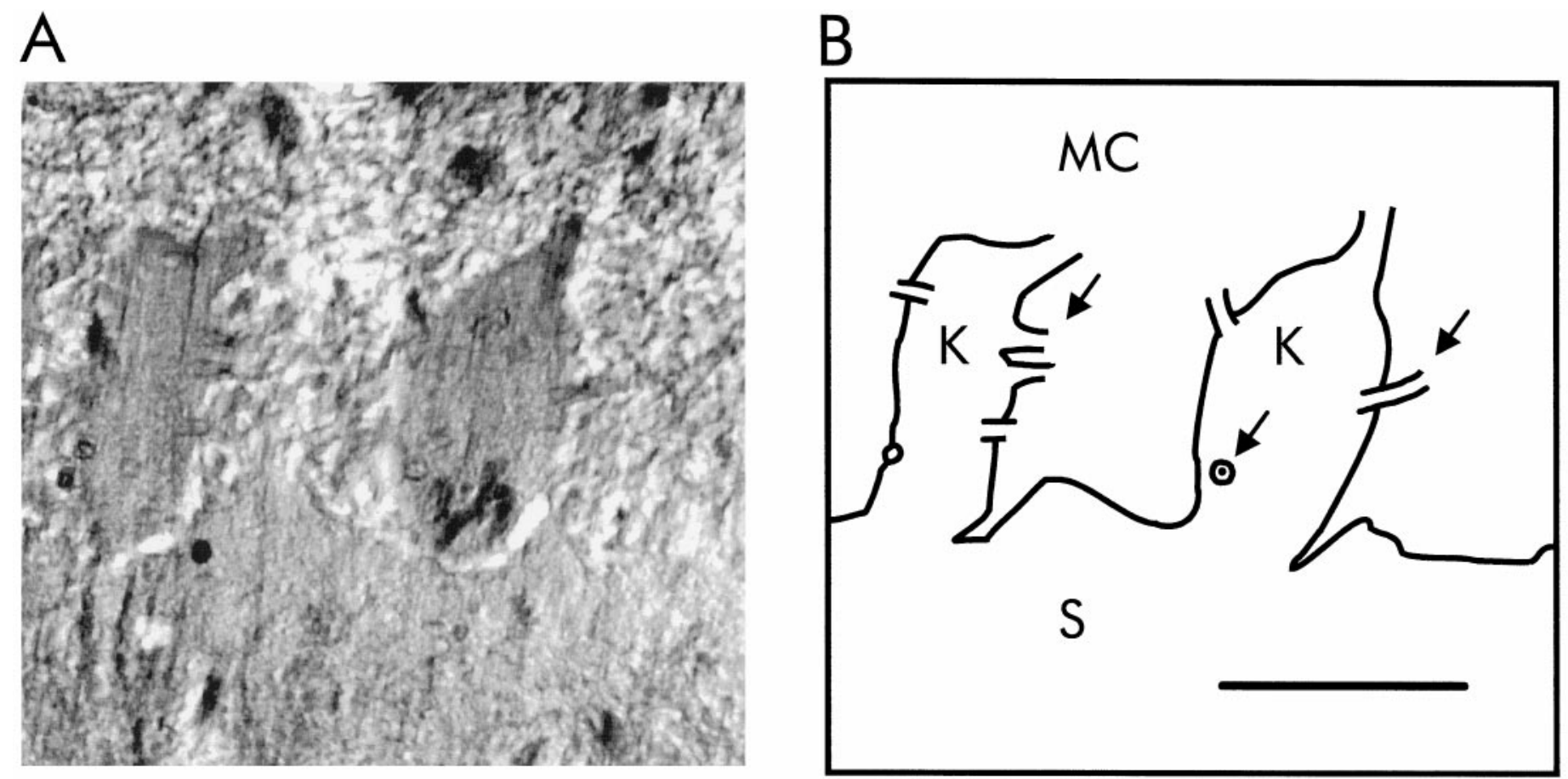

Figure 3. A, Electron micrograph of a 100-nm-thick cryosection of olfactory epithelium obtained by STEM. To preserve the physiological element distribution, this preparation was not stained. Structural details show differences in dry mass distribution and therefore are difficult to distinguish. $B$, Graphical representation of the main outlines that can be seen in $A$, showing mucociliary layer $(M C)$, dendritic knobs $(K)$, and supporting cells $(S)$. Arrows point to the basal parts of sensory cilia. Scale bar, $1 \mu \mathrm{m}$.

polymerized for $100 \mathrm{hr}$ at $70^{\circ} \mathrm{C}$. Sections of $100-500 \mathrm{~nm}$ thickness were prepared (Ultracut, Reichert-Jung) and photographed in a transmission electron microscope (TEM) (Philips EM 400 T).

\section{RESULTS}

To understand the ionic composition of receptor currents in rat OSNs, it is of primary interest to know the free concentrations (activities) of all ions involved in the transduction process. However, these concentrations cannot be measured with ion-selective microelectrodes because of the high viscosity of olfactory mucus and the small size of mucous layer, sensory cilia, and dendritic knobs. EDX microanalysis of freeze-dried cryosections prepared from shock-frozen tissue in an STEM yields the content of all elements relevant to the receptor current. In addition, the intensity of electron scattering (dark-field intensity) can be used to calculate the local water content that cryosections had before they were freeze-dried. The combined analysis of EDX spectra and electron scattering thus provides the local element concentration in millimoles per liter (Zierold, 1986). We have used this technique to measure the concentrations of $\mathrm{Cl}^{-}, \mathrm{K}^{+}$, and $\mathrm{Na}^{+}$in rat olfactory epithelium. Furthermore, we determined the relative element content (not the absolute concentrations) of olfactory mucus using isolated microsamples that were analyzed by EDX in a TEM. Finally, the relative element content was measured in a freeze-dried preparation of olfactory epithelium using EDX microanalysis in an SEM. The results obtained with these methods allowed calculation of the $\mathrm{Cl}^{-}$equilibrium potential in situ.

\section{Analysis of element concentrations in cryosections of olfactory epithelium}

To measure element concentrations in olfactory epithelium at high spatial resolution, we applied EDX microanalysis to ultrathin (100 nm thick) cryosections of shock-frozen epithelium.
Tissue samples were sectioned at $-125^{\circ} \mathrm{C}$, and freeze-dried cryosections were analyzed in a STEM at $-140^{\circ} \mathrm{C}$. This procedure prevents redistribution of elements during preparation of the sections and permits EDX microanalysis with a spatial resolution of $<0.1 \mu \mathrm{m}$. Figure $3 A$ shows a micrograph of an ultrathin cryosection of olfactory epithelium. To facilitate identification of tissue structures in the unstained section, outlines of the main structural features are presented in Figure $3 B$. Size and direction of $\mathrm{Cl}^{-}$currents are determined by the membrane voltage $\left(\mathrm{V}_{\mathrm{m}}\right)$ and by the $\mathrm{Cl}^{-}$equilibrium potential $\left(E_{\mathrm{Cl}}\right)$, which reflects the ratio of mucosal and ciliary $\mathrm{Cl}^{-}$concentrations $\left(\mathrm{Cl}_{\text {mucus }} / \mathrm{Cl}_{\text {cilia }}\right)$. It was not possible to reliably measure the $\mathrm{Cl}^{-}$concentration in cryosections of single cilia. However, measurements were feasible in sections of dendritic knobs (designated $K$ in Fig. $3 B$ ), which we assume to have the same ion composition as the ciliary lumen. We measured element concentrations in dendritic knobs and in adjacent regions of olfactory mucus, both measurements usually $<3$ $\mu \mathrm{m}$ apart. For comparison, cytosolic element concentrations were determined in supporting cells within the same sections. The results are summarized in Table 1. Element concentrations found in the cytosol of supporting cells are similar to values reported from other epithelia (Thurau et al., 1981; Hentschel and Zierold, 1994). A strikingly high $\mathrm{Cl}^{-}$concentration (69 mM) was detected in dendritic knobs, whereas contents of $\mathrm{K}^{+}, \mathrm{Na}^{+}, \mathrm{P}$, and $\mathrm{S}$ are in the range characteristic for cytosolic elements. The concentrations in olfactory mucus of $\mathrm{Na}^{+}$and $\mathrm{Cl}^{-}$(both $55 \mathrm{~mm}$ ) are clearly lower than in interstitial fluid, whereas the $\mathrm{K}^{+}$concentration (69 $\mathrm{mm}$ ) is much higher.

The $\mathrm{Cl} / \mathrm{K}$ ratio has a characteristic range of values for each fluid compartment. $\mathrm{Cl} / \mathrm{K}$ ratios of $10-30$ are found in blood serum (Zierold, 1992) and interstitial fluid ([Cl- $]=100-120 \mathrm{mM}$; 


\begin{tabular}{llcc}
\hline \multicolumn{3}{l}{ Table 1. Element concentrations in rat olfactory epithelium } \\
Element & $\begin{array}{l}\text { Olfactory mucus } \\
(n=12)\end{array}$ & $\begin{array}{l}\text { Dendritic knobs } \\
(n=10)\end{array}$ & $\begin{array}{l}\text { Supporting cells } \\
(n=6)\end{array}$ \\
\hline $\mathrm{Cl}$ & $55 \pm 11$ & $69 \pm 19$ & $32 \pm 12$ \\
$\mathrm{~K}$ & $69 \pm 10$ & $172 \pm 23$ & $147 \pm 13$ \\
$\mathrm{Na}$ & $55 \pm 12$ & $53 \pm 31$ & $28 \pm 12$ \\
$\mathrm{P}$ & $77 \pm 13$ & $134 \pm 21$ & $240 \pm 44$ \\
$\mathrm{~S}$ & $57 \pm 12$ & $174 \pm 23$ & $107 \pm 11$
\end{tabular}

$\overline{\text { Mean element concentrations }\left(c_{\mathrm{w}} \text {, in } \mathrm{mm} \pm \mathrm{SD}\right) \text { determined by EDX microanalysis }}$ of cryosections (STEM) from two animals.

$\left.\left[\mathrm{K}^{+}\right]=3-5 \mathrm{~mm}\right)$. For cytosolic fluid, characteristic values are 0.05-0.2 (Thurau et al., 1981) $\left(\left[\mathrm{Cl}^{-}\right]=5-30 \mathrm{~mm} ;\left[\mathrm{K}^{+}\right]=130-\right.$ $150 \mathrm{~mm}$ ). We determined the mucosal $\mathrm{Cl} / \mathrm{K}$ ratio in 45 measurements obtained from six animals, using EDX microanalysis of cryosections in the STEM. Each measurement was obtained from an area of $0.25-4 \mu \mathrm{m}^{2}$ within the mucociliary layer (designated $M C$ in Fig. 3), taking care that cilia were excluded from the area of recording. The mean $\mathrm{Cl} / \mathrm{K}$ ratio was $0.80 \pm 0.36$, and the variability of results is small compared with the 100 -fold difference between $\mathrm{Cl} / \mathrm{K}$ ratios of cytosolic and interstitial fluids.

$\mathrm{Cl} / \mathrm{K}$ ratios can also be accurately determined in isolated mucus samples, as well as in freeze-dried, fractured olfactory epithelium. We therefore measured $\mathrm{Cl} / \mathrm{K}$ ratios in these preparations to test the consistency of our results obtained with three preparation methods. The two additional methods, however, do not provide absolute element concentrations because no information about the original water content of the samples can be obtained.

\section{Determination of $\mathrm{Cl} / \mathrm{K}$ and $\mathrm{Ca} / \mathrm{K}$ ratios in microsamples of olfactory mucus}

The mucociliary layer in vivo forms a highly viscous fluid compartment of 5-20 $\mu \mathrm{m}$ thickness covering the olfactory epithelium in medial and caudal areas of the olfactory conchae. To prepare mucus samples for EDX microanalysis, a method must be used that allows isolation of samples without damaging the epithelial tissue underneath. If parts of tissue are removed together with the mucus sample, contaminations by interstitial fluid or by cytosol can cause significant changes of element concentrations in the sample. To avoid damaging the epithelium, we used carboncoated nylon grids (200 mesh), which were brought into gentle contact (for 1-2 sec) with the intact epithelial surface. After removal from the tissue, small amounts of mucus remained attached to the grid (Fig. $4 A$ ) and were air-dried and subjected to EDX microanalysis in a TEM. EDX spectra like the one shown in Figure $4 B$ were used to determine the peak-to-background ratios of $\mathrm{Cl}^{-}$- and $\mathrm{K}^{+}$-specific signals. We determined the $\mathrm{Cl} / \mathrm{K}$ ratios in 77 measurements from 13 microsamples obtained from four rats and obtained a mean value of $0.63 \pm 0.28$, which is close to the value measured in cryosections. A list of the results for each animal is given in Table 2 . The differences in $\mathrm{Cl} / \mathrm{K}$ ratios between animals are small, and the low mean value indicates no significant contamination by interstitial fluid $(\mathrm{Cl} / \mathrm{K}$ ratio, 10 to 30$)$.

Mucosal $\mathrm{Ca}^{2+}$ ions are of critical importance for olfactory transduction, and the free $\mathrm{Ca}^{2+}$ concentration in rat olfactory mucus is unknown. The EDX spectra recorded from microsamples showed a small but significant $\mathrm{Ca}$-specific signal (Fig. $4 B)$. Although the $\mathrm{Ca}$ signal is partly hidden by a $K_{\mathrm{K} \beta}$ peak (Barbi, 1979), it could be measured after a peak deconvolution
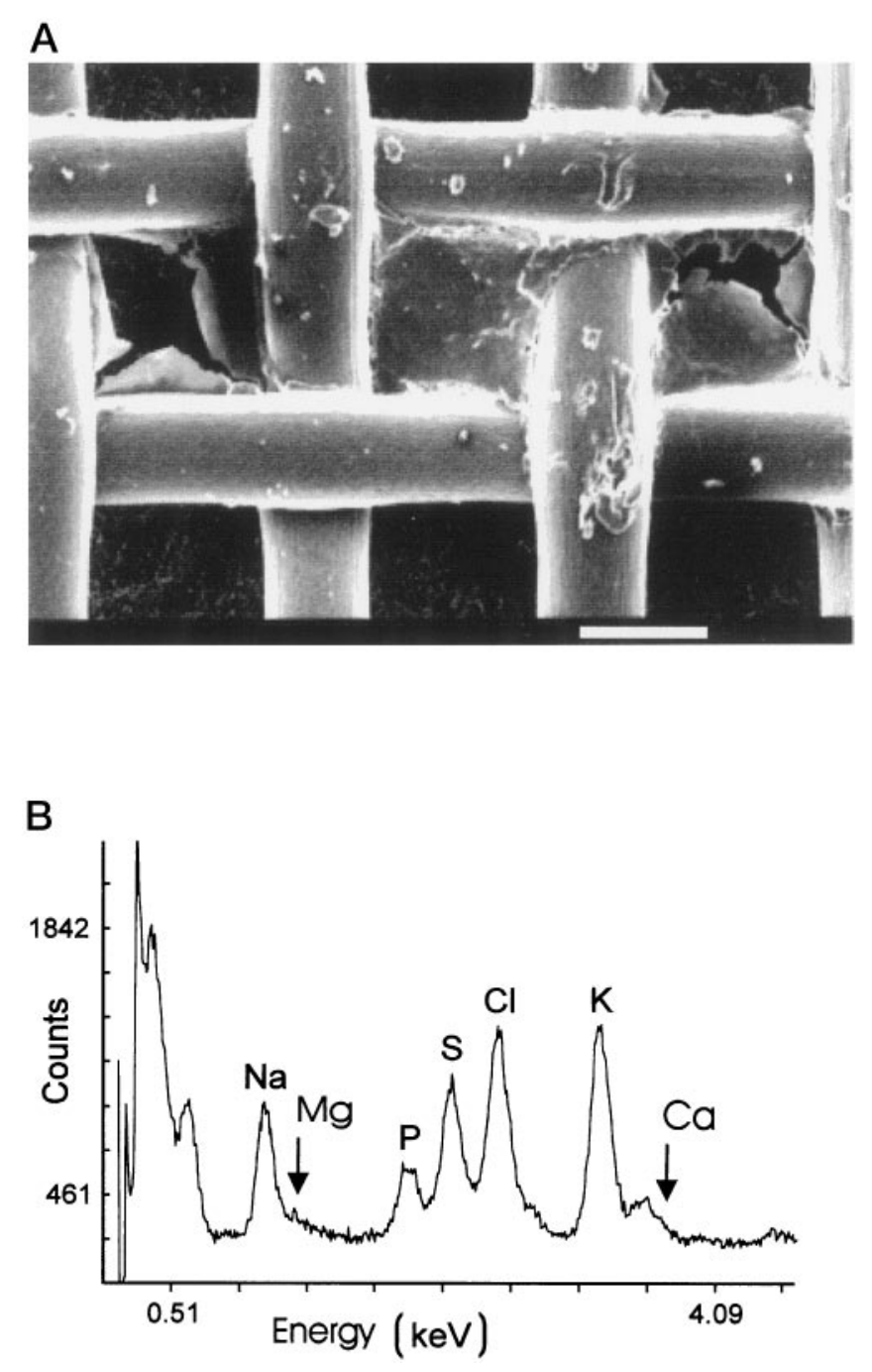

Figure 4. Determination of $\mathrm{Cl} / \mathrm{K}$ ratios in isolated samples of olfactory mucus. $A$, Scanning electron micrograph of a nylon grid containing a small sample of desiccated olfactory mucus. Scale bar, $100 \mu \mathrm{m}$. B, EDX spectrum obtained from an isolated mucus sample. The characteristic peaks $\left(\mathrm{K}_{\alpha}\right)$ are designated with element symbols. The $\mathrm{Mg}$ peak is near the detection limit, and the Ca signal is partially hidden under the $\mathrm{K}_{\mathrm{K} \beta}$ peak.

Table 2. $\mathrm{Cl} / \mathrm{K}$ and $\mathrm{Ca} / \mathrm{K}$ ratios measured in microsamples of olfactory mucus

\begin{tabular}{llll} 
Animal number & Measurements & $\mathrm{Cl} / \mathrm{K}$ ratio & $\mathrm{Ca} / \mathrm{K}$ ratio \\
\hline 1 & 32 & $0.35 \pm 0.22$ & $0.08 \pm 0.06$ \\
2 & 15 & $1.02 \pm 0.17$ & $0.19 \pm 0.10$ \\
3 & 11 & $0.62 \pm 0.44$ & $0.02 \pm 0.01$ \\
4 & 19 & $0.53 \pm 0.23$ & $0.12 \pm 0.11$
\end{tabular}

Mean ratio values \pm SD determined using the peak-to-background method from EDX spectra of isolated mucus samples.

procedure (Fain and Schröder, 1985). We calculated a mean $\mathrm{Ca} / \mathrm{K}$ ratio of $0.11 \pm 0.07$ (77) from the experiments shown in Table 2. With the measured mucosal $\mathrm{K}^{+}$concentration of $69 \pm 10$ $\mathrm{mM}$, this result indicates a total mucosal $\mathrm{Ca}$ concentration of $7.6 \pm 5.9 \mathrm{~mm}$. However, data from the four animals show substantial variations (Table 2 ) that may be attributed in part to the 


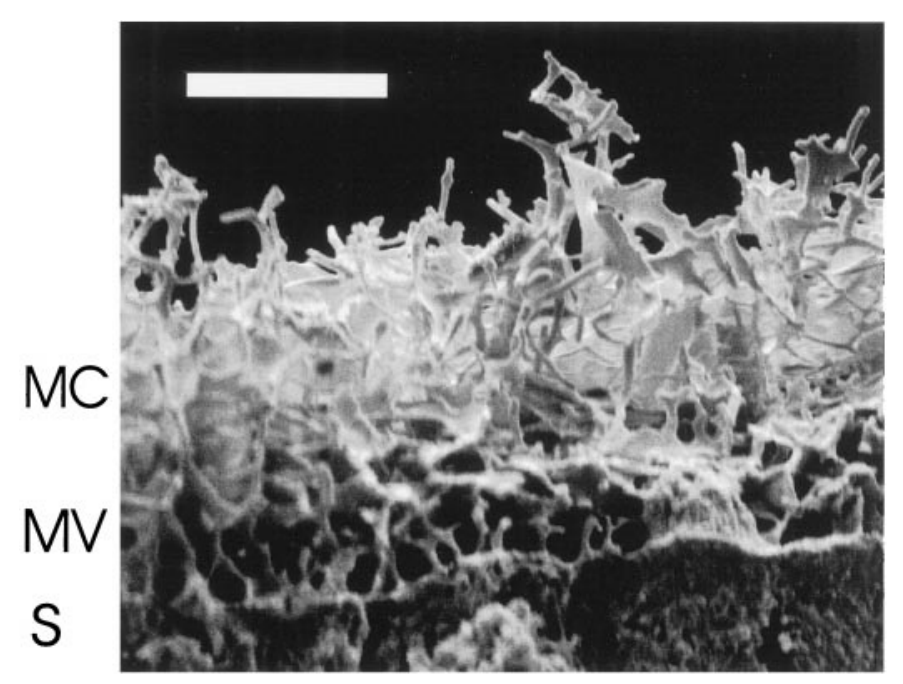

Figure 5. Scanning electron micrograph of the mucociliary layer in a freeze-dried preparation of rat olfactory epithelium showing mucociliary complex $(M C)$, microvilli of supporting cells $(M V)$, and apices of supporting cells $(S)$. Scale bar, $10 \mu \mathrm{m}$.

fact that the $\mathrm{Ca}$ signals are close to the detection limit of the system. This result therefore must be regarded as an upper limit of the total mucosal $\mathrm{Ca}$ concentration, and it contains no information about the free concentration of $\mathrm{Ca}^{2+}$ ions in olfactory mucus.

\section{Determination of the mucosal $\mathrm{Cl} / \mathrm{K}$ ratio in the freeze- dried mucociliary layer}

As a third independent test, we measured $\mathrm{Cl} / \mathrm{K}$ ratios within the mucociliary layer of olfactory epithelium that was shock-frozen, freeze-dried, fractured, and prepared for EDX microanalysis in a SEM. Figure 5 shows an electron micrograph of the mucociliary complex which was obtained from the preparation shown in Figure $1 A$. The sensory cilia can be seen as a tangle of tubular structures above the apical portion of supporting cells with their microvilli. Desiccated olfactory mucus covers the cilia and forms thin membranes of dried protein between individual cilia. Using this preparation, it was possible to measure $\mathrm{Cl} / \mathrm{K}$ ratios in the mucociliary complex in situ by EDX microanalysis. The mean value, calculated from peak-to-background ratios of $\mathrm{Cl}$ - and K-specific signals in the preparation shown in Figure 5, was $0.34 \pm 0.02$ (3). Because the internal lumen of cilia constitutes only a small fraction of the total mucociliary volume $(<7 \%)$ (Getchell et al., 1984), contaminations by ciliary cytosol are small, and the EDX measurements give a good approximation of the relative element contents of olfactory mucus. No measurements of cytosolic or interstitial element distributions were possible with this preparation, because the electron beam penetrates up to 10 $\mu \mathrm{m}$ into the tissue (Rick et al., 1979) and generates a complex signal that originates from both tissue compartments.

Thus, mucosal $\mathrm{Cl} / \mathrm{K}$ ratios measured in cryosections, in isolated microsamples, and in freeze-dried olfactory epithelium are between 0.3 and 0.8 , reflecting relative element concentrations in olfactory mucus that are different from both interstitial and cytosolic fluids. The consistency of these results indicates that element concentrations were not altered by the preparation techniques and suggests that the data given in Table 1 are a good estimate of mucosal element concentrations.

\section{Estimation of the $\mathrm{Cl}^{-}$-equilibrium potential across the ciliary membrane}

With the two assumptions that (1) the $\mathrm{Cl}^{-}$concentration measured by EDX microanalysis represents the free $\mathrm{Cl}^{-}$concentration within the respective compartment and (2) that the $\mathrm{Cl}^{-}$ concentrations in cilia and dendritic knobs are equal, the $\mathrm{Cl}^{-}$ equilibrium potential $\left(E_{\mathrm{Cl}}\right)$ can be calculated using the measured $\mathrm{Cl}^{-}$concentrations of $55 \pm 11 \mathrm{~mm}$ (12) for mucus $\left(\mathrm{Cl}_{\text {mucus }}\right)$ and $69 \pm 19 \mathrm{~mm}(10)$ for dendritic knobs $\left(\mathrm{Cl}_{\text {cilia }}\right)$ :

$$
E_{\mathrm{Cl}}=\frac{R T}{z F} \times \ln \frac{C l_{\text {mucus }}}{C l_{\text {cilia }}}
$$

where $R$ is the gas constant, $T$ is the absolute temperature, $z$ is the valence of the transported ion, and $F$ is the Faraday constant. With $R T / z F=-26.7 \mathrm{mV}$, we obtain a value for $E_{\mathrm{Cl}}$ of $+6.0 \pm 12.5$ $\mathrm{mV}$ and can now predict the direction of current flow through $\mathrm{Ca}^{2+}$-gated $\mathrm{Cl}^{-}$channels $\left(I_{\mathrm{Cl}}\right)$ in the ciliary membrane with:

$$
I_{\mathrm{Cl}}=g_{\mathrm{Cl}} \times\left(V_{\mathrm{m}}-E_{\mathrm{Cl}}\right)
$$

where $g_{\mathrm{C} 1}$ indicates the $\mathrm{Cl}^{-}$conductance generated by an odorant-induced increase of ciliary $\mathrm{Ca}^{2+}$ concentration. The resting membrane voltage of rat OSNs $\left(\mathrm{V}_{\mathrm{m}}\right)$ in situ has not been determined so far. Microelectrode studies with salamander OSNs in situ yielded values between -74 and $-56 \mathrm{mV}$ (Trotier and MacLeod, 1983; Hedlund et al., 1987). Values obtained from isolated amphibian OSNs (Firestein and Werblin, 1987; Frings and Lindemann, 1988; Kurahashi, 1989), as well as the properties of voltage-gated ion channels in mammalian OSNs (Maue and Dionne, 1987; Trombley and Westbrook, 1991; Rajendra et al., 1992), suggest that $\mathrm{V}_{\mathrm{m}}$ is in the range of -90 to $-50 \mathrm{mV}$. With $\mathrm{V}_{\mathrm{m}}=-70 \mathrm{mV}$ and $E_{\mathrm{Cl}}=+6 \mathrm{mV}$, we obtain with equation (2):

$$
I_{\mathrm{Cl}}=g_{\mathrm{Cl}}(-76 \mathrm{mV})
$$

The negative polarity indicates that $I_{\mathrm{Cl}}$ is a depolarizing inward current, carried by $\mathrm{Cl}^{-}$flux from the ciliary lumen into the mucus. Consequently, activation of ciliary $\mathrm{Cl}^{-}$channels during odorant response amplifies depolarization and electrical excitation of the OSN.

\section{DISCUSSION}

Chemoelectrical signal transduction in OSNs leads to the generation of a receptor current that is conducted by cAMP-gated cation channels and $\mathrm{Ca}^{2+}$-gated $\mathrm{Cl}^{-}$channels across the membrane of sensory cilia. To understand this process, one has to take into account that the cilia are not in contact with interstitial fluid but are embedded in olfactory mucus. Several reports have shown that mucosal ion concentrations determine direction, amplitude, and time course of current flow during odorant detection (Kurahashi and Shibuya, 1990; Frings et al., 1991; Kurahashi and Yau, 1993; Firestein and Shepherd, 1995). Of particular interest are the free concentrations of $\mathrm{Ca}^{2+}, \mathrm{Cl}^{-}, \mathrm{Na}^{+}$, and $\mathrm{K}^{+}$, because these ions are conducted by the two channel types activated during stimulation. It is difficult, however, to measure these concentrations because the delicate structures of olfactory epithelium and mucus layer, as well as the high viscosity of olfactory mucus, impede the application of most methods for element analysis, including ion-selective microelectrodes. Only few and, in part, divergent data on the element content of olfactory mucus have been published so far. Using atomic-absorption spectroscopy, $\mathrm{Na}^{+}, \mathrm{K}^{+}$, and $\mathrm{Ca}^{2+}$ concentrations were determined in mucus samples removed from olfactory epithelium with filter paper. 
Joshi et al. (1987) reported $53 \mathrm{~mm} \mathrm{Na}^{+}, 11 \mathrm{~mm} \mathrm{~K}^{+}$, and $5 \mathrm{~mm}$ $\mathrm{Ca}^{2+}$ in frog (Rana pipiens), whereas Bronshtein and Leontev (1972) found $105 \mathrm{mM} \mathrm{Na}^{+}$and $70 \mathrm{mM} \mathrm{K}^{+}$in frog (Rana temporaria), and $76 \mathrm{mM} \mathrm{Na}^{+}$and $77 \mathrm{mM} \mathrm{K}^{+}$in guinea pig (Cavia cobaya) olfactory mucus. In toad (Bufo marinus) olfactory mucus, Chiu et al. (1989) detected free concentrations of $93 \mathrm{~mm} \mathrm{Cl}^{-}, 85$ $\mathrm{mM} \mathrm{Na}{ }^{+}, 11 \mathrm{mM} \mathrm{K}{ }^{+}$, and $0.32 \mathrm{mM} \mathrm{Ca}^{2+}$, using ion-selective microelectrodes. It is difficult to compare these data with the concentrations we have found in cryosections of rat olfactory epithelium $\left(55 \mathrm{mM} \mathrm{Cl}^{-}, 55 \mathrm{~mm} \mathrm{Na}^{+}\right.$, and $\left.69 \mathrm{mM} \mathrm{K}^{+}\right)$because contaminations by cytosol or interstitial fluid were not rigorously excluded in the published studies. In particular, the relatively low $\mathrm{K}^{+}$concentration and the $\mathrm{Cl} / \mathrm{K}$ ratio of 9 in the microelectrode study may indicate contamination by interstitial fluid $(\mathrm{Cl} / \mathrm{K}$ ratio, 10 to 30 ). In the present study, we consistently found $\mathrm{Cl} / \mathrm{K}$ ratios $<1$ in olfactory mucus. This discrepancy, however, may also reflect differences in mucosal ion content between mammals and amphibians.

Our estimate for the mucosal $\mathrm{Cl}^{-}$concentration $(55 \mathrm{~mm})$ is somewhat higher than the concentrations reported for other secretions. In pancreatic, gastric, and salivary secretions, the $\mathrm{Cl}^{-}$ concentration is $20-50 \mathrm{~mm}$, whereas the $\mathrm{Cl} / \mathrm{K}$ ratios are between 1 and 6 (Davson and Segal, 1975). Thus, $\mathrm{Cl}^{-}$and $\mathrm{K}^{+}$concentrations in olfactory mucus are higher than in many fluids with high protein content secreted by exocrine glands. The mucosal $\mathrm{Cl}^{-}$ concentration is lower, however, than in interstitial fluid or in secretions of the nasal respiratory epithelium, which has an ion content similar to interstitial fluid and blood plasma (Widdicombe and Wells, 1982). This low mucosal $\mathrm{Cl}^{-}$concentration favors the efflux of $\mathrm{Cl}^{-}$ions at negative membrane voltages when $\mathrm{Ca}^{2+}$ gated $\mathrm{Cl}^{-}$channels are activated.

Interestingly, the ciliary $\mathrm{Cl}^{-}$concentration in OSNs $(69 \mathrm{~mm}$, measured in dendritic knobs) is significantly higher than in most neurons where an intracellular $\mathrm{Cl}^{-}$concentration of 5-10 mM supports an $E_{\mathrm{Cl}}$ value close to the resting membrane voltage (Yamashita and Wässle, 1991). This strongly negative $E_{\mathrm{C} 1}$ provides the driving force for hyperpolarizing $\mathrm{Cl}^{-}$currents that are induced by GABA and glycine, the major inhibitory neurotransmitters in the vertebrate CNS (Vandenberg and Schofield, 1994). However, in developing hippocampal cells, GABA-receptor stimulation induces depolarizing currents (Cherubini et al., 1991; Michelson and Wong, 1991). This appears to be the consequence of an elevated cytosolic $\mathrm{Cl}^{-}$concentration that reflects a low $\mathrm{Cl}^{-}$ permeability of the plasma membrane specific for this early stage

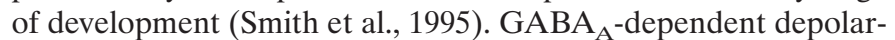
izing $\mathrm{Cl}^{-}$currents were also reported for pituitary cells (Zhang and Jackson, 1993, 1995) and for cultured melanotrophs (Le Foll et al., 1998). In both cases, the intracellular $\mathrm{Cl}^{-}$concentrations were estimated to be $20-26 \mathrm{~mm}\left(E_{\mathrm{Cl}}=-48\right.$ to $\left.-38 \mathrm{mV}\right)$. Relatively high cytosolic concentrations have also been reported for non-neuronal cells. In salivary acinar cells, cytosolic $\mathrm{Cl}^{-}$is maintained at $50-66 \mathrm{~mm}$ by the activity of $\mathrm{Cl}^{-}-\mathrm{HCO}_{3}{ }^{-}$exchangers and $\mathrm{Na}^{+}-\mathrm{K}^{+}-2 \mathrm{Cl}^{-}$cotransporters (for review, see Nauntofte, 1992). This high level of cytosolic $\mathrm{Cl}^{-}$facilitates $\mathrm{Cl}^{-}$ secretion in these cells. It is tempting to speculate that rat OSNs use similar transport mechanisms for the accumulation of cytosolic $\mathrm{Cl}^{-}$, to sustain a depolarizing $\mathrm{Cl}^{-}$efflux during odorant stimulation.

Our EDX measurements of $\mathrm{Cl}^{-}$concentrations in dendritic knobs and olfactory mucus yielded a value of the ciliary $\mathrm{Cl}^{-}$ equilibrium potential of $+6 \pm 12 \mathrm{mV}$. Previous studies of $\mathrm{Ca}^{2+}$ activated $\mathrm{Cl}^{-}$currents in OSNs were performed using isolated neurons (Kurahashi and Yau, 1993; Lowe and Gold, 1993; Firestein and Shepherd, 1995; Zhainazarov and Ache, 1995) or isolated cilia preparations (Kleene, 1993). In these studies, the $\mathrm{Cl}^{-}$-equilibrium potential across the ciliary membrane was either unknown, or $E_{\mathrm{Cl}}$ was adjusted experimentally to values between -40 and $+60 \mathrm{mV}$ by dialyzing cilia through the patch pipette. In most studies, isolated OSNs or isolated cilia were kept in Ringer's solution with higher $\mathrm{Cl}^{-}$concentrations $(120-150 \mathrm{~mm})$ than in the olfactory mucus $(55 \mathrm{~mm})$. The ciliary $\mathrm{Cl}^{-}$concentration in isolated OSNs is not known and may be different from OSNs in situ, so that $\mathrm{Cl}^{-}$contributions to the receptor current in vivo are difficult to predict from experiments with isolated cells. In two studies, $E_{\mathrm{Cl}}$ was measured with intact isolated amphibian OSNs in Ringer's solution, using the perforated-patch technique. The values reported for Necturus maculosus $\left(E_{\mathrm{Cl}}=-45 \mathrm{mV}\right.$ ) (Dubin and Dionne, 1994) and Xenopus laevis $\left(E_{\mathrm{Cl}}=-2.3 \mathrm{mV}\right)$ (Zhainazarov and Ache, 1995) suggest that the ciliary $\mathrm{Cl}^{-}$concentration of isolated OSNs is in the range of $30-120 \mathrm{~mm}$. It is not apparent from the currently available data whether these concentrations represent the physiological $\mathrm{Cl}^{-}$content of OSNs in these animals or whether they result from cell damage during the isolation procedure.

Taken together, our data suggest that $\mathrm{Ca}^{2+}$-gated $\mathrm{Cl}^{-}$channels in the sensory cilia of the rat conduct a depolarizing efflux of $\mathrm{Cl}^{-}$ions because of an elevated ciliary and a low mucosal $\mathrm{Cl}^{-}$ concentration. As proposed earlier (Kurahashi and Yau, 1993, 1994; Lowe and Gold, 1993; Firestein and Shepherd, 1995; Zhainazarov and Ache, 1995; Kleene and Pun, 1996; Kleene, 1997), the resulting $\mathrm{Cl}^{-}$current may contribute significantly to the depolarizing receptor current in mammalian and amphibian OSNs. In mammals, the $\mathrm{Cl}^{-}$component may serve to amplify the sensory signal and to contribute to the detection efficiency of the olfactory system. Our data indicate that both $\mathrm{Na}^{+}$and $\mathrm{K}^{+}$ions carry depolarizing inward currents at $-70 \mathrm{mV}\left(E_{\mathrm{Na}}=+1.0 \pm\right.$ $21.4 \mathrm{mV} ; E_{\mathrm{K}}=-24 \pm 7.2 \mathrm{mV}$ ) when $\mathrm{CNG}$ channels open during stimulation by odorants. Because, however, monovalent currents through CNG channels are strongly blocked at negative membrane voltage by millimolar concentrations of mucosal $\mathrm{Ca}^{2+}$ and $\mathrm{Mg}^{2+}$ (Kurahashi and Shibuya, 1990; Zufall and Firestein, 1993; Frings et al., 1995), the contribution of $\mathrm{Na}^{+}$and $\mathrm{K}^{+}$to the receptor current is probably small. It thus appears that the main function of CNG channels is to provide an entry pathway for $\mathrm{Ca}^{2+}$ into the cilia, mediating a cAMP-dependent increase of the ciliary $\mathrm{Ca}^{2+}$ concentration that induces a depolarizing $\mathrm{Cl}^{-}$ efflux.

In sweet-water fish and some amphibians, where the olfactory mucus can be in direct contact with the ambient water, mucosal $\mathrm{Na}^{+}$and $\mathrm{K}^{+}$concentrations are probably much lower than in mammals. Consequently, $\mathrm{CNG}$ channels will conduct only a small net current, composed of $\mathrm{Ca}^{2+}$ influx and $\mathrm{K}^{+}$efflux, that may even be hyperpolarizing (if $E_{\mathrm{K}}$ is more negative then the resting membrane voltage). Under these conditions, $\mathrm{Ca}^{2+}$-gated $\mathrm{Cl}^{-}$ channels can sustain a depolarizing receptor current sufficient for sensory function, as was demonstrated recently by Kleene and Pun (1996). It thus appears that chemoelectrical signal transduction is independent of $\mathrm{Na}^{+}$and $\mathrm{K}^{+}$in the mucosal medium and solely dependent on the presence of mucosal $\mathrm{Ca}^{2+}$. The free $\mathrm{Ca}^{2+}$ concentration in mammalian olfactory mucus is probably similar to sweet water ( $\sim 1 \mathrm{~mm}$ ) (Joshi et al., 1987; Chiu et al., 1989), so that activation of $\mathrm{Ca}^{2+}$-permeable $\mathrm{CNG}$ channels can trigger a receptor current that is carried almost entirely by $\mathrm{Cl}^{-}$ ions. 


\section{REFERENCES}

Bakalyar HA, Reed RR (1990) Identification of a specialized adenylyl cyclase that may mediate odorant detection. Science 250:1403-1406.

Barbi NC (1979) Quantitative methods in biological x-ray microanalysis. Scanning Electron Microsc 2:659-672.

Boekhoff I, Tareilus E, Strotmann J, Breer H (1990) Rapid activation of alternative second messenger pathways in olfactory cilia from rats by different odorants. EMBO J 9:2453-2458.

Borisy FF, Ronnett GV, Cunningham D, Juilfs D, Beavo J, Snyder SH (1992) Calcium/calmodulin-activated phosphodiesterase expressed in olfactory receptor neurons. J Neurosci 12:915-923.

Breer H, Wanner I, Strotmann J (1996) Molecular genetics of mammalian olfaction. Behav Genet 26:209-219.

Bronshtein AA, Leont'ev VG (1972) The sodium and potassium content of the mucus of the olfactory epithelium of vertebrates. J Evol Biochem Physiol 8:520-524.

Buck LB (1996) Information coding in the vertebrate olfactory system. Annu Rev Neurosci 19:517-544.

Chen TY, Yau KY (1994) Direct modulation by $\mathrm{Ca}^{2+}$-calmodulin of cyclic nucleotide-activated channel of rat olfactory receptor neurons. Nature 368:545-548.

Cherubini E, Gaiarsa JL, Ben-Ari Y (1991) GABA: an excitatory transmitter in early postnatal life. Trends Neurosci 14:515-519.

Chiu D, Nakamura T, Gold GH (1989) Ionic composition of toad olfactory mucus measured with ion selective microelectrodes. Chem Senses 13:677-678.

Davson H, Segal MB (1975) Introduction to physiology. New York: Academic.

Dubin AE, Dionne VE (1994) Action potentials and chemosensitive conductances in the dendrites of olfactory neurons suggest new features for odor transduction. J Gen Physiol 103:181-201.

Fain GL, Schröder WH (1985) Calcium content and calcium exchange in dark-adapted toad rods. J Physiol (Lond) 368:641-665.

Firestein S, Shepherd GM (1995) Interaction of anionic and cationic currents leads to a voltage dependence in the odor response of olfactory receptor neurons. J Neurophysiol 73:562-567.

Firestein S, Werblin FS (1987) Gated currents in isolated olfactory receptor neurons of the larval tiger salamander. Proc Natl Acad Sci USA 84:6292-6296.

Frings S, Lindemann B (1988) Odorant response of isolated olfactory receptor cells is blocked by amiloride. J Membr Biol 105:233-243.

Frings S, Benz S, Lindemann B (1991) Current recording from sensory cilia of olfactory receptor cells in situ. II. Role of mucosal $\mathrm{Na}^{+}, \mathrm{K}^{+}$, and $\mathrm{Ca}^{2+}$ ions. J Gen Physiol 97:725-747.

Frings S, Seifert F, Godde M, Kaupp UB (1995) Profoundly different calcium permeation and blockage determine the specific function of distinct cyclic nucleotide-gated channels. Neuron 15:169-179.

Getchell TV, Margolis FL, Getchell ML (1984) Perireceptor and receptor events in vertebrate olfaction. Prog Neurobiol 23:317-345.

Getchell ML, Zielinski B, Getchell TV (1988) Odorant and autonomic regulation of secretion in the olfactory mucosa. In: Molecular neurobiology of the olfactory system (Margolis FL, Getchell TV, eds), pp 71-98. New York: Plenum.

Hallani M, Lynch JW, Barry PH (1998) Characterization of calciumactivated chloride channels in patches excised from the dendritic knob of mammalian olfactory receptor neurons. J Membr Biol 161:163-171.

Hedlund B, Masukawa LM, Shepherd GM (1987) Excitable properties of olfactory receptor neurons. J Neurosci 7:2338-2343.

Hentschel H, Zierold K (1994) Morphology and element distribution of magnesium-secreting epithelium: the proximal tubule segment PII of dogfish, Scyliorhinus caniculus (L.) Eur J Cell Biol 63:32-42.

Joshi H, Getchell ML, Zielinski B, Getchell TV (1987) Spectrophotometric determination of cation concentrations in olfactory mucus. Neurosci Lett 82:321-326.

Kerjaschki D, Hörandner H (1976) The development of mouse olfactory vesicles and their cell contacts. J Ultrastruct Res 54:420-444.

Kleene SJ (1993) Origin of chloride current in olfactory transduction. Neuron 11:123-132.

Kleene SJ (1997) High-gain, low-noise amplification in olfactory transduction. Biophys J 73:1110-1117.

Kleene SJ, Gesteland RC (1991) Calcium-activated chloride conductance in frog olfactory cilia. J Neurosci 11:3624-3629.

Kleene SJ, Pun RYK (1996) Persistence of the olfactory receptor cur- rent in a wide variety of extracellular environments. J Neurophysiol 75:1386-1391.

Kleene SJ, Gesteland RC, Bryant SH (1994) An electrophysiological survey of frog olfactory cilia. J Exp Biol 195:307-328.

Kurahashi T (1989) Activation by odorants of cation-selective conductance in the olfactory receptor cell isolated from the newt. J Physiol (Lond) 419:177-192.

Kurahashi T, Menini A (1997) Mechanism of odorant adaptation in the olfactory receptor cell. Nature 385:725-729.

Kurahashi T, Shibuya T (1990) $\mathrm{Ca}^{2+}$-dependent adaptive properties in the solitary olfactory receptor cell of the newt. Brain Res 515:261-268,

Kurahashi T, Yau KW (1993) Co-existence of cationic and chloride components in odorant-induced current of vertebrate olfactory receptor cells. Nature 363:71-74.

Kurahashi T, Yau KW (1994) Tale of an unusual chloride current. Curr Biol 4:256-258.

Le Foll F, Castel H, Soriani O, Vaudry H, Cazin L (1998) Gramicidinperforated patch revealed depolarizing effect of GABA in cultured frog melanotrophs. J Physiol (Lond) 507:55-69.

Leinders-Zufall T, Rand MN, Shepherd GM, Greer CA, Zufall F (1997) Calcium entry through cyclic nucleotide-gated channels in individual cilia of olfactory receptor cells: spatiotemporal dynamics. J Neurosci 17:4136-4148.

Lowe G, Gold GH (1993) Nonlinear amplification by calcium-dependent chloride channels in olfactory receptor cells. Nature 366:283-286.

Lowe G, Nakamura T, Gold GH (1989) Adenylate cyclase mediates olfactory transduction for a wide variety of odorants. Proc Natl Acad Sci USA 86:5641-6545.

Maue RA, Dionne VE (1987) Patch-clamp studies of isolated mouse olfactory receptor neurons. J Gen Physiol 90:95-125.

Menco BM (1995) Freeze-fracture, deep-etch, and freeze-substitution studies of olfactory epithelia, with special emphasis on immunocytochemical variables. Microsc Res Tech 32:337-356.

Michelson HB, Wong RKS (1991) Excitatory synaptic responses mediated by $\mathrm{GABA}_{\mathrm{A}}$ receptors in the hippocampus. Science 253:1420-1423.

Nakamura T, Gold GH (1987) A cyclic nucleotide-gated conductance in olfactory receptor neurons. Nature 325:442-444.

Nauntofte B (1992) Regulation of electrolyte and fluid secretion in salivary acinar cells. Am J Physiol 263:G823-G837.

Rajendra S, Lynch JW, Barry PH (1992) An analysis of $\mathrm{Na}^{+}$currents in rat olfactory receptor neurons. Pflügers Arch 420:342-346.

Rick R, Dörge A, Bauer R, Gehring K, Thurau K (1979) Quantification of electrolytes in freeze-dried cryosections by electron microprobe analysis. Scanning Electron Microsc 2:619-626.

Schröder WH, Fain GL (1984) Light-dependent calcium release from photoreceptors measured by laser micro-mass analysis. Nature 309:268-270.

Seveus L (1980) Cryoultramicrotomy as a preparation technique for x-ray microanalysis. Scanning Electron Microsc 4:161-170.

Smith RL, Clayton GH, Wilcox CL, Escudero KW, Staley KJ (1995) Differential expression of an inwardly rectifying chloride conductance in rat brain neurons: a potential mechanism for cell-specific modulation of postsynaptic inhibition. J Neurosci 15:4057-4067.

Spurr AR (1969) A low viscosity embedding medium for electron microscopy. J Ultrastruct Res 1:239-246.

Thurau K, Beck F, Mason J, Dörge A, Riek R (1981) Inside the cell: an electron microprobe analysis of the renal tubular electrolyte concentrations. In: Epithelial ion and water transport (Macknight ADC, Leader JP, eds), pp 137-145. New York: Raven.

Trombley PQ, Westbrook GL (1991) Voltage-gated currents in identified rat olfactory receptor neurons. J Neurosci 11:435-444.

Trotier D, MacLeod P (1983) Intracellular recordings from salamander olfactory receptor cells. Brain Res 268:225-237.

Vandenberg RJ, Schofield PR (1994) Inhibitory ligand-gated ion channel receptors: molecular biology and pharmacology of $\mathrm{GABA}_{\mathrm{A}}$ and glycine receptors. In: Handbook of membrane channels. Molecular and cellular physiology (Peracchia C, ed), pp 317-332. New York: Academic.

Widdicombe JG, Wells UM (1982) Airway secretions. In: The nose. Upper airway physiology and the atmospheric environment (Proctor DF, Andersen I, eds), pp 215-244. Amsterdam: Elsevier.

Yamashita M, Wässle H (1991) Reversal potential of GABA-induced currents in rod bipolar cells of the rat retina. Vis Neurosci 6:399-401.

Zhainazarov AB, Ache BW (1995) Odor-induced currents in Xenopus olfactory receptor cells measured with perforated-patch recording. J Neurophysiol 74:479-483. 
Zhang SJ, Jackson MB (1993) GABA-activated chloride channels in secretory nerve endings. Science 259:531-534.

Zhang SJ, Jackson MB (1995) GABA $_{\mathrm{A}}$ receptor activation and the excitability of nerve terminals in the rat posterior pituitary. J Physiol (Lond) 483:583-595.

Zierold K (1982) Cryopreparation of mammalian tissue for x-ray microanalysis in STEM. J Microsc 125:149-156.

Zierold K (1986) The determination of wet weight concentrations of elements in freeze-dried cryosections from biological cells. Scanning Electron Microsc 2:713-724.

Zierold K (1988) X-ray microanalysis of freeze-dried and frozenhydrated cryosections. J Electron Microsc Tech 9:65-82.
Zierold K (1992) Comparison of cryopreparation techniques for electron probe microanalysis of cells as exemplified by human erythrocytes. Scanning Microsc 6:1137-1145.

Zierold K, Hentschel H, Wehner F, Wessing A (1994) Electron probe $\mathrm{x}$-ray microanalysis of epithelial cells: aspects of cryofixation. Scanning Microsc [Suppl] 8:117-127.

Zufall F, Firestein S (1993) Divalent cations block the cyclic nucleotidegated channel of olfactory receptor neurons. J Neurophysiol 69:1758-1768.

Zufall F, Firestein S, Shepherd GM (1994) Cyclic nucleotide-gated ion channels and sensory transduction in olfactory receptor neurons. Annu Rev Biophys Biomol Struct 23:577-607. 